\title{
Spillover Effects of Budgetary Policies in Monetary Union: The Case of WAEMU
}

\author{
Chérif Sidy Kane, Ismaila Sanghare \\ Faculty of Economics and Management (FASEG), Cheikh Anta DIOP University of Dakar (UCAD), Dakar, Senegal \\ Email: cherifsidy@y ahoo.fr, cherifsidy.kane@ucad.edu.sn, Sanghare78@yahoo.fr
}

How to cite this paper: Kane, C.S. and Sanghare, I. (2018) Spillover Effects of Budgetary Policies in Monetary Union: The Case of WAEMU. Theoretical Economics Letters, 8, 3492-3508.

https://doi.org/10.4236/tel.2018.815215

Received: August 27, 2018

Accepted: December 3, 2018

Published: December 6, 2018

Copyright (c) 2018 by authors and Scientific Research Publishing Inc. This work is licensed under the Creative Commons Attribution International License (CC BY 4.0).

http://creativecommons.org/licenses/by/4.0/

\begin{abstract}
With the help of a vector model for dynamic panel error correction (PVEC), this article examines the extent to which a country's policy shocks spread to the economic activity of other countries in the West African Economic and Monetary Union (WAEMU). The results of one part, the emergence of externalities that cause asymmetric shocks and another part, the public expenditure shocks induce greater spillover effects on economic growth than public revenue shocks. Both results imply the structural heterogeneity of economies, leading to an uneven distribution of the benefits and costs of a common monetary policy. Therefore, corrective measures can be applied, through a real policy mix, which can reduce the risks of instability related to budgetary externalities.
\end{abstract}

\section{Keywords}

Budget Externality, Structural Heterogeneity, PVEC Model, WAEMU

\section{Introduction}

Like the euro zone, the West African Economic and Monetary Union (WAEMU) is a monetary union with no central or federal budget. Thus, in times of financial stress, governments cannot rely on the funding of a national central bank, which strengthens ex-ante budgetary discipline but makes countries more fragile ex-post. The absence of both national monetary policies and a common budget places the burden of stabilization on national budgetary policies [1].

This form of integration leads to an arrangement of macroeconomic policies whose benefits focus on the facilitation of intra-community trade [2], on the reduction of the inflation rate of the countries [3] and on lowering interest rates and increasing investment [4]. However, the costs of macroeconomic policy flexibility appear for those countries that can no longer use monetary policy to 
stabilize economic cycles.

Given the resurgence of exogenous shocks, budgetary policies, despite their consequences, remain the only means by which balance can be restored. These consequences, known as "Spillover Effects", continue to fuel the debate in search of optimal solutions for monetary unions. Indeed, the excessive use of the budget instrument amplifies the level of public deficits thus generating externalities that question its effectiveness.

In analyzing the stability of budgetary policy in WAEMU, Diop and Diaw [5] show that shocks to public capital spending do not lead to inflationary pressures and positively influence private sector investment in Benin, Mali, Morocco and Senegal. On the other hand, the control of the evolution of public consumption expenditure seems important since they are very sensitive to inflation in States like Cote d'Ivoire and Senegal. They also find that shocks to the tax burden rate have only negative effects on the economic activity of the union states and also on the private consumption of households, hence a strict control of its evolution so as not to not create distortions in the economies of the area.

In the Economic and Monetary Community of Central Africa (EMCCA), Ondo Ossa [6] finds that the negative externalities created by excessive deficits in some countries may impact on others and cause pressure on the central bank through public debts. In this respect, a member country that does not ensure the solvency of its public finances automatically poses a risk to the financial stability of the area, through a rise in long-term interest rates.

In view of these theoretical and empirical cleavages, the purpose of this article is to determine the nature of the externalities of budgetary policies and, secondly, to assess their magnitude on the economic activity of the WAEMU countries.

The choice of WAEMU as a field of investigation is justified for three reasons: first, the presence of structural heterogeneity requires devoting significant stabilizing power to fiscal policies [7], then economies are highly open and vulnerable to exogenous shocks and finally the presence of asynchronous economic cycles requires coordination of budgetary policies [8].

We use panel VARs that not only solve the problem of endogeneity of the regressors but also simulate independent structural shocks between them and the macroeconomic environment in order to confirm or refute a monetary or budgetary explanation of the economic fluctuations [9] [10].

The purpose of this paper is to present first the theoretical foundations of the effects of overflow of fiscal policies 1), then the methodology 2) and finally the results 3 ), before concluding on their implications in terms of economic policies.

\section{Economic Literature on the Budgetary Policies Spillovers}

At the theoretical level, there is some divergence on the effects of budgetary policies. While Keynesians believe that budgetary policy can stimulate aggregate demand and revive the economy through the multiplier mechanism, the new classics [11] [12], show that stabilization budgetary policy has no favorable effect 
on economic activity; since governments use it very often for electoral and non-regulatory purposes; public deficits would generally be too high, leading to a large accumulation of public debt.

Thus, the neo-realist or intergovernmentalist theory, emphasizing the importance of domestic policies in community spaces, emphasizes that the core priorities of national governments remain their own programs [13]. In the same logic, the theory of areas of natural integration ${ }^{1}$ of the New Economic Geography highlights the "border effects" which admit that when the institutional preference zones do not cover the areas of natural integration, the spillover effects are important; this may have trade implications [14] [15].

Economic and trade integration is a bulwark against asymmetric shocks [16], but the emergence of budgetary externalities in currency unions questions the effectiveness of budgetary policy as an instrument for regulating economic activity. The single monetary policy can no longer correct the effects of a demand shock [17] [18].

In the euro area, Persson and Tebellini [19] argue that budgetary policies can generate significant externalities and risks to the sustainability of public finances. Indeed, economies are interdependent to the point that a country's Areas where countries are naturally close and whose transactions are facilitated by this proximity policies affect the economic performance of neighboring countries. But Gros and Hobza [20] point out that, in general, the externalities of the budget are weak or even insignificant in the European Union. On the other hand, the work of Beetsma et al. [21] highlights positive externalities through the foreign trade channel.

Auerbach and Gorodnichenko [22] showed from a study of a panel of 30 OECD countries (mostly euro area countries) that the spillover effects of budget shocks are more important during periods of recession. Similar analysis carried out in the WAEMU space confirms the existence of spillover effects of countries' budgetary policies through the trade channel [5] [23], but these works identify only a few channels of transmission of shocks without specifying the extent of the spread of these shocks on the economic growth of the countries of the union.

Empirical works variously appreciated the budgetary spillover effects in currency unions. From a structural VAR model, Sarr [23] shows that an increase in public spending can increase national inflation and average inflation of WAEMU if the central bank reacts with a restrictive monetary policy, this can negatively affect the activity of all the member countries of the union. Thus, the credibility of budgetary policy appears to be strongly linked to the degree of convergence of the WAEMU economies [8]. It is therefore easy to notice that the deterioration of a country's budgetary position sends a bad signal to investors who modify their risk behavior with regard to government securities [24].

\section{Methodology for Evaluation of Budgetary Externalities}

We use a dynamic panel vector error correction model (PVEC) or panel vector

${ }^{1}$ Areas where countries are naturally close and whose transactions are facilitated by this proximity. 
autoregressive (PVAR) to study the magnitude of the spread of budgetary policy shocks on the economic activity of the countries of the West African Economic and Monetary Union (WAEMU).

$$
\begin{gathered}
y_{i t}=A_{1} y_{i t-1}+A_{2} y_{i t-2}+\cdots+A_{p-1} y_{i t-p+1}+A_{p} y_{i t-p}+B X_{t}+\varepsilon_{i t} \\
E\left(\varepsilon_{i t}\right)=0 \quad \text { and } \quad E\left(\varepsilon_{i t} \varepsilon_{i t}^{\prime}\right)=\sum_{t \geq s} E\left(\varepsilon_{i t} \varepsilon_{i s}^{\prime}\right)=0
\end{gathered}
$$

where $y_{i t}$ it is the vector of endogenous variables; $X_{i t}$ it represents the vector of the exogenous variables; $\varepsilon_{i t}$ are the error terms. The parameters to be estimated are the components of matrices $A_{1}, A_{2}, \cdots, A_{p-1}, A_{p}$ and $B$.

The estimation of a PVEM or PVAR will depend on the stationarity of the variables but also on the cointegration relation between these variables. Then, to specify the final model, the following steps are considered: the stationarity test, the determination of the optimal number of delays, the granger causality test, the estimate of the coefficients by the generalized method of moments, the test of stability for model validation, the variance decomposition of forecast by Cholesky method, and the impulse response functions.

In terms of the theoretical review, we use endogenous variables (gross domestic product, government debt, government revenues, government expenditures and imports) and exogenous variables (inflations, gross fixed capital formation and credits). The statistics (1980-2016) come from the database of the Central Bank of West African States (BCEAO) and the Word Development Indicator (WDI) of the World Bank.

\section{Presentation of the Results of the Estimates}

To ensure the reliability of the results, we carried out 3 tests taking into account the individual heterogeneity (IPS test, Hadri test, Breitung test).

The results in the annexes indicate that, with the exception of the inflation rate, all the variables are integrated of order 1 (Table A1) and the optimal number of delays is evaluated at 2 (Table A2). We note the existence of three cointegration relationships, which justifies the estimate of a PVEC model (Table 1).

Table 1. Johansen cointegration test.

\begin{tabular}{ccccc}
\hline \multicolumn{5}{c}{ Variables : LPIBHBT LDEP LRECETTE LDETTE LIMPORT } \\
\hline \multicolumn{5}{c}{ Period : 19802016} \\
\cline { 1 - 1 } Hypothesis: & Fisher Stat & Prob & Fisher Stat & \multirow{2}{*}{ Prob } \\
\cline { 1 - 2 } Nber of Coint Eq & (trace test) & & (p. valeur test) & \\
\hline None & 152.8 & 0 & 94.84 & 0 \\
At least 1 & 73.87 & 0 & 46.58 & 0 \\
At least 2 & 36.39 & 0.0009 & 25.8 & 0.0274 \\
At least 3 & 19.88 & 0.134 & 12.59 & 0.559 \\
At least 4 & 18.2 & 0.1979 & 18.2 & 0.1979 \\
\hline
\end{tabular}

Source: Author's estimate. 
The stability of PVEC is a prerequisite for the study of impulse responses. Based on our results, it is found that the characteristic roots of the delay polynomial associated with our estimated PVEC are within the unit circle of the complex plane. Hence, it comes down to concluding on the stability of the estimated PVEC model. Figure 1 is illustrative.

Based on these results, we estimate the following model for the analysis of impulse responses:

$$
\begin{aligned}
& \int \text { lpibhbt }_{i t}=\alpha_{1}+\sum_{j=1}^{p-1}\left(\beta 1_{j} \Delta \text { lpibhbt }_{i t-j}+\gamma 1_{j} \Delta \text { ldep }_{i t-j}+\lambda 1_{j} \Delta \text { lrecette }_{i t-j}\right.
\end{aligned}
$$

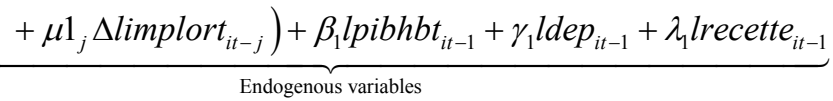

$$
\begin{aligned}
& +\underbrace{\mu_{1} \text { limplort }_{i t-1}+\delta 1_{1} \Delta l f b c f_{i t}+\delta 1_{2} \text { infpib }_{i t}+\delta 1_{3} \Delta \text { lcredit }_{i t}+\tau 1_{i t}}_{\text {Exogenous variables }} \\
& \Delta l d e p_{i t}=\alpha_{2}+\sum_{j=1}^{p-1}\left(\beta 2_{j} \Delta \text { lpibhbt }_{i t-j}+\gamma 2_{j} \Delta \text { ldep }_{i t-j}+\lambda 2_{j} \Delta \text { lrecette }_{i t-j}\right.
\end{aligned}
$$

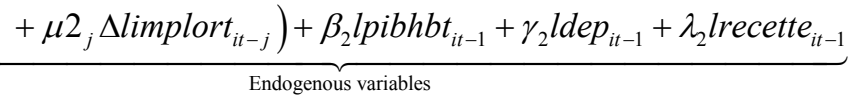

$$
\begin{aligned}
& +\underbrace{\mu_{2} \text { limplort }_{i t-1}+\delta 2_{1} \Delta l f b c f_{i t}+\delta 2_{2} \text { infpib }_{i t}+\delta 2_{3} \Delta \text { lcredit }_{i t}+\tau 2_{i t}}_{\text {Exogenous variables }} \\
& \Delta \text { lrecette }_{i t}=\alpha_{3}+\sum_{j=1}^{p-1}\left(\beta 3_{j} \Delta \text { lpibhbt }_{i t-j}+\gamma 3_{j} \Delta l d e p_{i t-j}+\lambda 3_{j} \Delta_{\text {lrecette }} \text { lit }-j\right.
\end{aligned}
$$

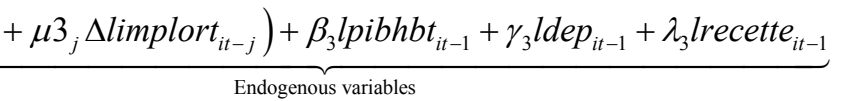

$$
\begin{aligned}
& +\underbrace{\mu_{3} \text { limplort }_{i t-1}+\delta 3_{1} \Delta l f b c f_{i t}+\delta 3_{2} i n f p i b_{i t}+\delta 3_{3} \Delta l c r e d i t_{i t}+\tau 3_{i t}}_{\text {Exogenous variables }} \\
& \text { slimport }_{i t}=\alpha_{4}+\sum_{j=1}^{p-1}\left(\beta 4_{j} \Delta \text { lpibhbt }_{i t-j}+\gamma 4_{j} \Delta \text { ldep }_{i t-j}+\lambda 4_{j} \text { slrecette }_{i t-j}\right.
\end{aligned}
$$

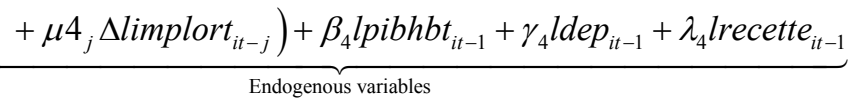

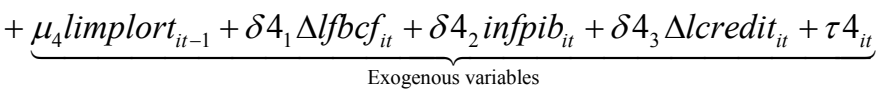

Notice :

- The index $i$ represents a given country, $t$ the time dimension, the operator $\Delta$ indicates the first difference;

- $\quad \beta, \delta, \gamma, \mu$ and $\lambda$ are the coefficients of the different variables and $p$ is the optimal delay;

- $\tau_{i t}$ is the residue of the model;

- $\quad \alpha$ is the constant

The results of the estimate are shown in Appendix Table A3 and Figure A1. We can see that the granger causality test (Table A4 in the appendix) confirms the existence of causality between the different endogenous variables. In addition, the autocorrelation of residues test (Table A5 in the appendix) allows us to conclude that there is no autocorrelation; these results, combined with the stability of the model, ensure the robustness of the estimates.

\section{a) Analysis of the variance decomposition of the forecast error}

Considering a time horizon of ten years, the results from the variance decomposition allow us to better understand the dynamics of the variables (Table 2). 
Inverse Roots of AR Characteristic Polynomial

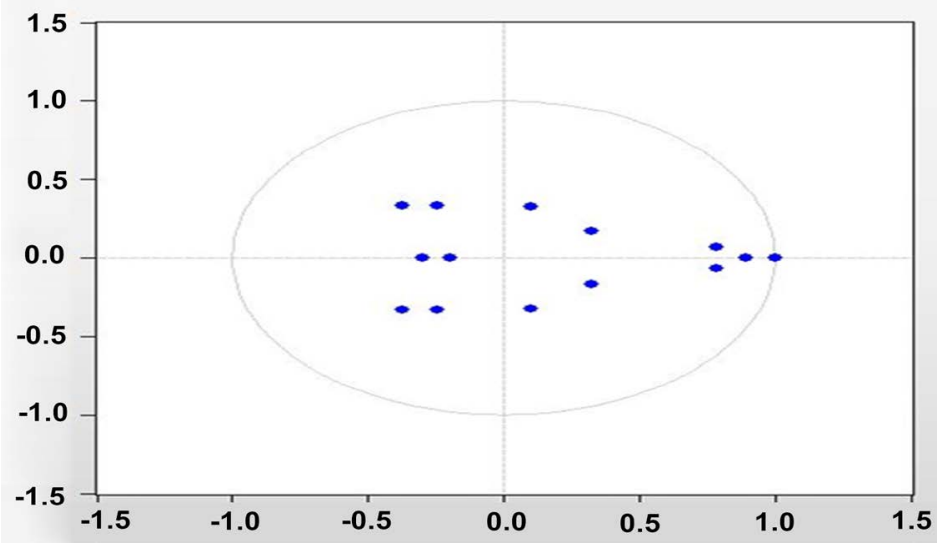

Figure 1. PVEC stability test.

Table 2. Variance decomposition of the forecast error.

\begin{tabular}{cccccc}
\hline $\begin{array}{c}\text { Part of the } \\
\text { Variance (in \%) }\end{array}$ & LPIBHBT & LDEP & LRECETTE & LIMPORT & LDETTE \\
\hline LPIBHBT & $\mathbf{9 4 . 0 2 8 5}$ & 0.3517 & $\mathbf{5 . 2 8 9 6}$ & 0.2281 & 0.1022 \\
LDEP & 0.6215 & $\mathbf{9 0 . 0 5 9 9}$ & 1.1109 & $\mathbf{8 . 0 1 8 2}$ & 0.1894 \\
LRECETTE & 15.0379 & 12.5290 & 59.9485 & 11.9346 & 0.5500 \\
LIMPORT & 0.9076 & 6.3507 & 0.7108 & 91.6197 & 0.4111 \\
LDETTE & 1.7857 & 2.3321 & 2.5979 & 1.2151 & 92.0691 \\
\multicolumn{7}{c}{ Decomposition by line for the 10-year horizon } \\
\hline
\end{tabular}

Source: author's calculation.

- Fluctuations in per capita income mainly come from its own innovations (94.03\%) and tax revenues (5.29\%). Public spending, imports and public debt have a marginal influence $(0.35 \%, 0.22 \%, 0.1 \%)$, so this result reveals that a budgetary policy shock dissipates over time and does not significantly change per capita income fluctuations, which would confirm its cyclical effect and its limitations in dealing with the long-term problems defended by the proponents of the new anti-Keynesian theory.

- The evolution of public expenditure is explained by its own innovations (90.05\%) and imports (8.02\%). In fact, within WAEMU, public expenditure is mainly explained by the external part of the global offer. They are, to a lesser extent, influenced by tax revenues (1.1\%) and the low influence of debt (0.19\%) shows that public spending is done independently of debt dynamics.

- Regarding tax revenues, their variance is slightly affected by debt shocks with $0.55 \%$. Shocks in GDP per capita, government spending and imports significantly influence the variance of tax revenues (respectively $15.04 \%, 12.53 \%$, 11.93\%). This result reveals that public revenues are sensitive to these three variables and to their own innovations (59.95\%). In WAEMU, the influence of GDP per capita seems logical because tax revenues are mainly deducted from the income of economic activity and the impact of public expenditure is 
explained by a desire to improve the efficiency of the tax administration. The high dependence of WAEMU economies on imports also justifies its significant influence on the fluctuation of tax revenues.

- The variance of imports is determined by its own shocks (91.62\%) and public expenditure shocks (6.35\%). Indeed, public policies are focused on major investment programs, particularly in infrastructure, which requires a massive import of equipment but also completes the local supply for the satisfaction of operating expenses.

- For the public debt, the observation is that its medium-term variance depends almost on its own shocks, i.e. 92.07\%. Budget shocks (public spending and tax revenues) account for a total of 5\%. This shows that the debt of the WAEMU countries is driven by its own dynamics; it is not very sensitive to the strategies of development and management of public finances. However, the $5 \%$ contribution from the public authorities remains low and implies a slight involvement of the authorities in the management of the debt.

\section{b) Evaluation of the impact of budgetary externalities}

Spatial correlation matrices provide a qualitative analysis of the shocks that lead to budgetary spillover effects across countries. As an example, we find that a public expenditure shock in Benin is positively correlated with public expenditure shocks in Côte d'Ivoire but a public revenue shock in Benin is negatively correlated with a public revenue shock in Côte d'Ivoire.

The estimates of the effects of budget spillovers are recorded in the tables below (Table 3).

\section{- Impact of a budget shocks in Benin on the growth of the countries}

Figure 2 shows the impact of a public expenditure shock (bar in blue) and a public revenue shock (in clear green) in Benin on the economic growth of the different countries in the WAEMU. It shows a public expenditure shock in Benin has a negative effect on economic growth in two countries (Burkina Faso $(-0.031)$ and Mali $(-0.264))$ and a positive but not significant effect on the other countries of the union.

On the other hand, tax revenue shocks lead to positive spillover effects on economic growth in three countries (Burkina, Mali, Senegal) and negative in three countries (Côte d'Ivoire, Niger, Togo).

\subsection{Impact of a Budget Shocks in Burkina Faso on the Growth of the Countries}

The results reveal that a shock of public spending in Burkina Faso results in positive and significant spillover effects in three countries: Côte d'Ivoire (0.277), Niger (0.291) and Togo (0.151). However, the shock has a negative and significant impact on Mali's economic growth $(-0.211)$. For spillover effects resulting from a tax revenue shock, they are positive and significant in some countries, such as Senegal, Mali and Benin, with quite different amplitudes. As for other countries, the public revenue shock on economic growth is not significant (Figure 3). 
Table 3. Spatial correlation matrix of public expenditures and public revenue in WAEMU.

\begin{tabular}{|c|c|c|c|c|c|c|c|}
\hline & \multicolumn{7}{|c|}{ Correlation matrix of public expenditure } \\
\hline & BEN & BFA & CIV & MLI & NER & SEN & TGO \\
\hline BEN & 1 & & & & & & \\
\hline BFA & $0.3863^{* *}$ & 1 & & & & & \\
\hline CIV & $0.3100^{*}$ & $0.5359^{* * *}$ & 1 & & & & \\
\hline MLI & -0.066 & $-0.7690^{\star * *}$ & $-0.4197^{\star * \star}$ & 1 & & & \\
\hline NER & 0.2649 & -0.0668 & -0.2264 & -0.0426 & 1 & & \\
\hline SEN & $0.2905^{\star}$ & $0.4648^{* * *}$ & 0.0215 & $-0.5491^{* * *}$ & $0.6972^{* * *}$ & 1 & \\
\hline \multirow[t]{3}{*}{ TGO } & $0.5024^{* * *}$ & $0.5130^{* * *}$ & $0.7942^{* * *}$ & $-0.4699^{* * *}$ & 0.1842 & $0.3437^{* *}$ & 1 \\
\hline & \multicolumn{7}{|c|}{ Correlation matrix of public revenue } \\
\hline & BEN & BFA & CIV & MLI & NER & SEN & TGO \\
\hline BEN & 1 & & & & & & \\
\hline BFA & $0.6590^{* * *}$ & 1 & & & & & \\
\hline CIV & $-0.4535^{\star * *}$ & -0.1007 & 1 & & & & \\
\hline MLI & $0.6486^{* * *}$ & $0.3150^{*}$ & $-0.8486^{* * *}$ & 1 & & & \\
\hline NER & $0.5620^{* * *}$ & $0.8495^{* * *}$ & -0.1977 & $0.3304^{\star *}$ & 1 & & \\
\hline SEN & $0.6405^{* * *}$ & $0.7918^{* * *}$ & -0.1747 & $0.4011^{\star *}$ & $0.7277^{\star * *}$ & 1 & \\
\hline TGO & -0.1348 & $0.3296^{* *}$ & $0.7290^{\star * *}$ & $-0.5131^{* * *}$ & $0.3928^{* *}$ & 0.2344 & 1 \\
\hline
\end{tabular}

Source: Author’s Calculation. Significance: ${ }^{* *} 1 \%,{ }^{* *} 5 \%,{ }^{*} 1 \%$.

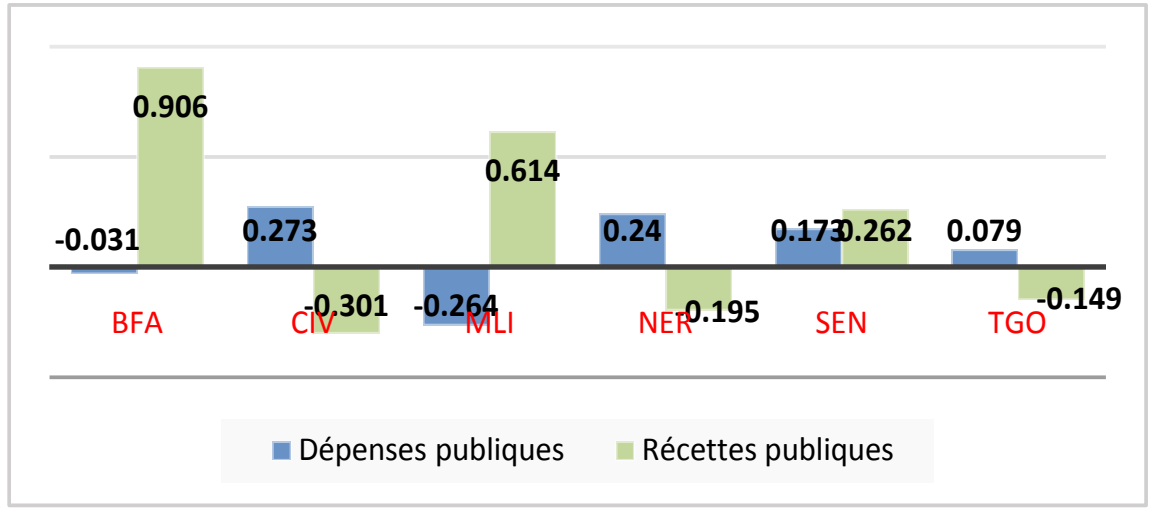

Figure 2. Budget shocks in Benin and economic growth of WAEMU countries. Source: author's Estimate.

\subsection{Impact of a Budget Shocks in Côte d'Ivoire on the Growth of the Countries}

A public spending shock in Côte d'Ivoire has negative effects on the economic growth of all the countries in the zone with the exception of Niger (0.322) and Togo (0.179). On the other hand, a tax revenue shock has positive effects only in Togo and Niger. In Senegal, the spillover effect is not significant (Figure 4). 


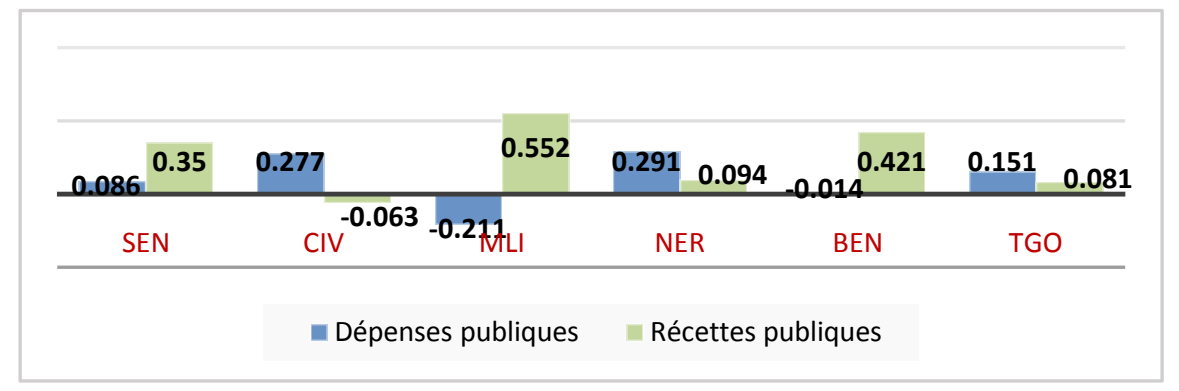

Figure 3. Budget shocks in Burkina Faso and economic growth in WAEMU countries. Source: Author's Estimate.

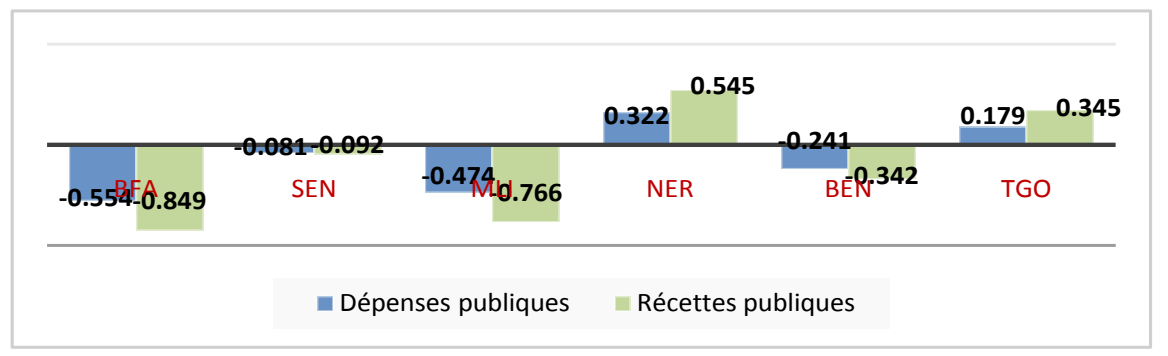

Figure 4. Budget shocks in Côte d'Ivoire and economic growth in WAEMU countries. Source: Author's Estimate.

\subsection{Impact of a Budget Shocks in Mali on the Growth of the Countries}

The results show that a public spending shock results in a very significant negative spillover effect on economic growth in Côte d'Ivoire (-0.338), Togo $(-0.211)$ and Niger $(-0.369)$. The impact of the shock on the economic growth of the other countries is not significant.

A tax revenue shock generates both positive and negative spillover effects. As for the negative effect, it concerns Côte d'Ivoire $(-0.449)$, Togo $(-0.215)$ and Niger $(-0.381)$. The magnitude is relatively higher compared to the effect of public spending. On the other hand, the spillover effect is positive in Burkina Faso (0.754), Benin (0.018) and Senegal (0.135) (Figure 5).

\subsection{Impact of a Budget Shocks in Niger on the Growth of the Countries}

Shocks to public spending produce positive spillover effects on economic growth in Benin (0.312), Burkina Faso (0.695), Mali (0.471) and Senegal (0.263). The impact is not significant in Côte d'Ivoire and Togo. With regard to tax revenue shocks, the spillover effect is positive for all countries except Côte d'Ivoire (Figure 6).

\subsection{Impact of a Budget Shock in Senegal on the Growth of the Countries}

The results reveal that a public spending shock creates positive externalities for all countries of the union with the exception of Côte d'Ivoire. On the other hand, 


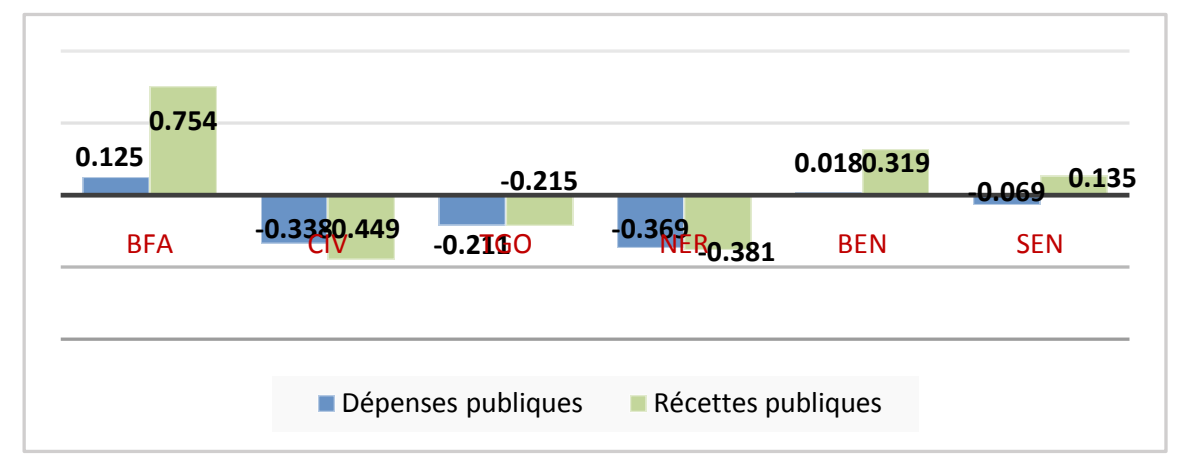

Figure 5. Budget shocks in Mali and economic growth of WAEMU countries. Source: Author's Estimate.

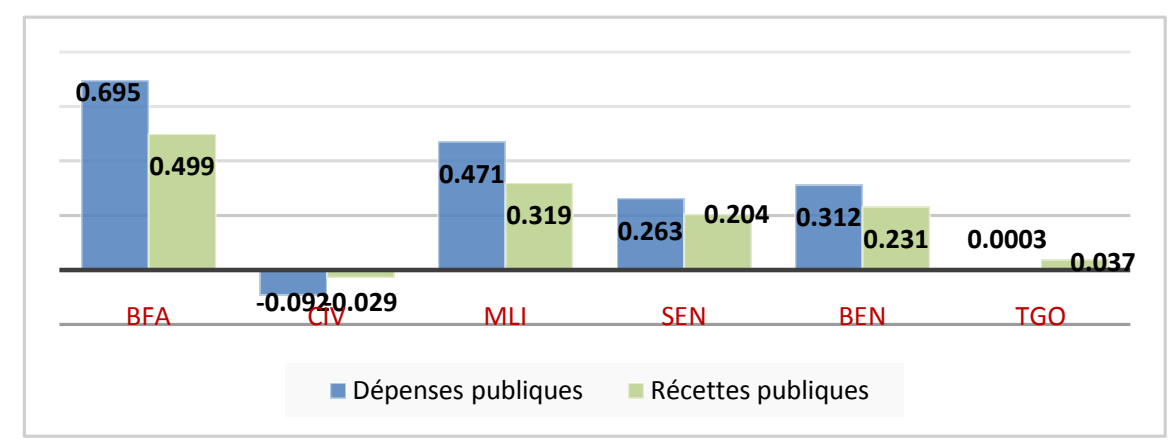

Figure 6. Budget shocks in Niger and economic growth of WAEMU countries. Source: Author's Estimate.

tax revenue shocks have positive spillover effects on the economic growth of countries such as Burkina (1.459), Mali (0.979) and Niger (0.692). On the other hand, the effects, although positive, are not significant in the other countries (Figure 7).

\subsection{Impact of a Budget Shock in Togo on the Growth of the Countries}

The results show that a public expenditure shock generates negative spillover effects on economic growth in Burkina (-0.27), Mali $(-0.313)$ and Benin $(-0.110)$. On the other hand, a tax revenue shock creates positive spillover effects in Niger (0.325) and Côte d'Ivoire (0.354). It remains negative in Mali (-0.167), but not significant in Burkina and Benin (Figure 8).

\section{Conclusion and Implication of Economic Policies}

The purpose of this paper was to analyze the effects of budgetary spillovers on the economic activity of the WAEMU countries using a dynamic panel vector error correction model (PVEC). Specifically, the objective was first to check whether a budgetary policy shock in one country produces similar effects in all neighboring countries and then to measure the impact of these fiscal externalities on the economic growth of each country. 


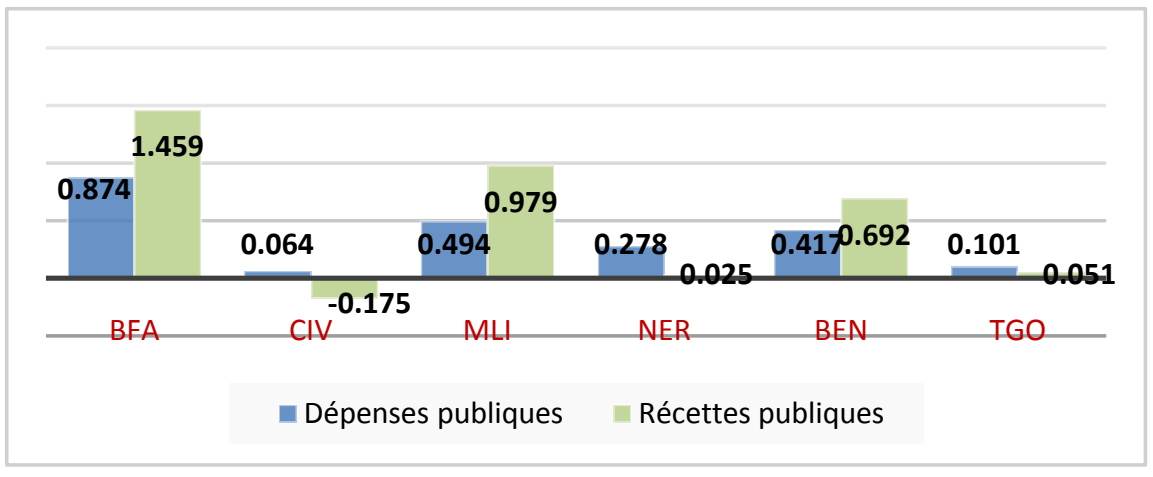

Figure 7. Budget shocks in Senegal and economic growth of WAEMU countries. Source: Author's Estimation de l'auteur.

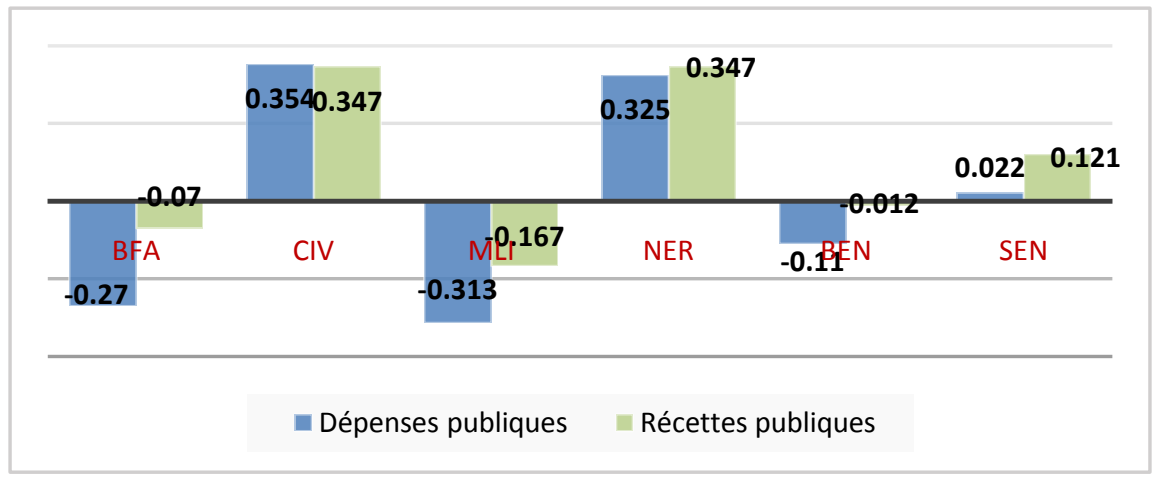

Figure 8. Budget shock in Togo and economic growth of UEMOA countries. Source: Author's Estimate.

The variance decomposition of the forecast error and the impulse response functions allowed us to see that the transmission delays of fiscal policy shocks are very short and that the economic activity is sensitive to the fluctuations of budgetary instruments. The results show that spillover effects vary according to the economic profile of each country and that a public expenditure shock is more important than a tax revenue shock on countries' economic growth. This difference results from the gradual harmonization of fiscal policies, while public spending is defined and implemented unilaterally by each country.

Moreover, Frankel and Rose [25] argue that a monetary union is conducive to the intensification of trade and the synchronization of economic cycles. However, an assessment of the extent of budgetary externalities within WAEMU found that the frequency of asymmetric shocks forces countries to constantly use budgetary policy to stabilize their economies. In a heterogeneous monetary union, the effectiveness of budgetary policies is limited by two phenomena:

1) The impact of negative budgetary externalities on the economic growth of neighboring countries.

2) The appearance of stowaway when budgetary externalities are favorable to neighboring countries.

Since budgetary policy is necessary to increase domestic production, it is 
essential that tariffs, internal indirect taxes and import quotas be coordinated. Such budget coordination has two advantages:

- to promote the convergence of production cycles, i.e. productivity.

- to prevent weak countries from losing tax revenue due to negative externalities.

In the case of WAEMU, the results confirm the structural heterogeneity of the economies. The single monetary policy is likely to be counter-cyclical in some countries and pro-cyclical in other countries, so this leads to conclude that there is a need to integrate heterogeneity into monetary rules. It must also be present in the process of budgetary arrangements to enable a proper allocation of the costs and benefits of belonging to a monetary union. At this level, it is desirable to design, for each WAEMU country, an optimal budget threshold corrected for cyclical effects. Indeed, these countries are exporters of raw materials (cotton, coffee, cocoa, groundnuts) and their budgetary balances are very sensitive to cyclical developments in world prices (exogenous shocks).

The Convergence, Stability, Growth and Solidarity Pact of the West African Economic and Monetary Union (WAEMU) should therefore integrate the management of budgetary externalities, which requires corrective measures, through a real policy mix, capable of reducing the risks of instability related to the spillover effects of budgetary policies.

The main limitation of this work is that it does not take into account the institutional and socio-political realities of the different countries of the zone. However, political and institutional instability can also have significant spillover effects on neighboring countries. It would therefore be important to continue thinking about taking these variables into account in future studies in order to achieve better results.

\section{Conflicts of Interest}

The authors declare no conflicts of interest regarding the publication of this paper.

\section{References}

[1] Bénassy-Quéré, et al. (2017) Politique Economique, debooeck supérieur, 4th Edition.

[2] Rose, A. and Engel, C. (2002) Currency Union and International Integration. Journal of Money, Credit and Banking, 34, 1067-1089. https://doi.org/10.1353/mcb.2002.0058

[3] Alesina, A., Barro, R. and Tenreyro, S. (2002) Optimal Currency Area. NBER Working Paper No. 9702.

[4] De Grauwe, P. (2000) Monetary Policy in the Presence of Asymmetries. Journal of Common Market Studies, 38, 593-612. https://doi.org/10.1111/1468-5965.00255

[5] Diop, M. and Diaw, A. (2015) Politique budgétaire et stabilité macroéconomique en union économique et monétaire: Le cas de l'UEMOA. OFCE|Revue de P OFCE, 137, 181-209. 
[6] Ondo Ossa, A. (2006). Effets anti-keynésiens et Ajustement, le cas de la zone CEMAC. Revue d Economie Appliquée, 6, 3-26.

[7] Coulibaly, M. (2013) Impact des dépenses publiques d'éducation sur la croissance économique en côte d'ivoire. European Scientific Journal, 9, 443-464.

[8] Kane, C.S. (2013) Synchronisation des cycles conjoncturels de la production industrielle dans l'UEMOA. Revue d Economie Appliquée, 1, Numéro 1.

[9] Blanchard, O.J. and Quah, D. (1989) The Dynamic Effect of Aggregate Demand and Supply Disturbances. American Economic Review, 79, 655-673.

[10] Canova, F. and Ciccarelli, M. (2013) Panel Vector Autoregressive Models a Survey. European Central Bank, Working Paper Series, No. 1507.

[11] Lucas, R. (1973) Some International Evidence on Output-Inflation Tradeoffs. American Economic Review, 63, 326-334.

[12] Barro, R. (1974) Are Government Bonds Net Wealth? Journal of Political Economy, 87, 940-971. https://doi.org/10.1086/260807

[13] Moravcsik A. (1993) Preferences and Power in the European Community: A liberal Intergovernmentalist Approach. Journal of Common Market Studies, 31, 473-524.

[14] Krugman P. (1991) Target Zones and Exchange Rate Dynamics. Quarterly Journal of Economics, 106, 669-682. https://doi.org/10.2307/2937922

[15] Siroën. J.M. (2000) La régionalisation de l'économie mondiale. Repères, Edition la Découverte Paris.

[16] Savall, C. (2013) Zone monétaire optimale: Quels efforts à faire pour la zone euro? Journal de l'Economie et Société, 10 septembre.

[17] Anglietta, M. and Boissieu, C.H. (1998) Rapport sur la coordination européenne des politiques économiques. $117 \mathrm{p}$.

[18] Frankel, J.A. and Rose, A. (2002) An Estimate of the Effect of Common Currencies on Trade and Income. Quarterly Journal of Economics, 117, 437-466. https://doi.org/10.1162/003355302753650292

[19] Persson, T. and Tabellini, G. (1995) Double-Edged Incentives: Institutions and Policy Coordination. In: Grossman, G. and Rogoff, K., Eds., Handbook of International Economics, Vol. III, Political Economy, Amsterdam, 223-247.

[20] Gros, D. and Hobza, A. (2001) Fiscal Policy Spillovers in the Euro Area: An Empirical Assessment. Document de travail du cepii, 2001-20.

[21] Beetsma, M.W.J. and Lans Bovenberg, A. (2001) The Optimality of a Monetary Union without a Fiscal Union. Journal of Money, Credit and Banking, 33, 179-204. https://doi.org/10.2307/2673880

[22] Auerbach, A.J. and Gorodnichenko, Y. (2012) Fiscal Multipliers in Recession and Expansion. American Economic Journal: Economic Policy, 1-40.

[23] Sarr, F. (2006) La coordination des politiques macroeconomiques en union monetaire: le cas de l'Union Economique et Monetaire Ouest Africaine. These de Doctorat LEO Universite d'Orlfeans.

[24] Sene, B. (2014) Soutenabilité de la dette publique et primes de risque sur les titres d'état en zone UEMOA. Revue d' Economie Appliquée, 2, 102-120.

[25] Frankel, J.A. and Rose, A.K. (1998) The Endogeneity of the Optimum Currency Area Criteria. Economic Journal, 108, 1009-1025. 


\section{Annexes}

Table A1. Stationarity test results.

\begin{tabular}{ccccc}
\hline & IPS & HDRI & BREITUNG & Décision finale \\
\hline lpibhbt & $\mathrm{I}(1)$ & $\mathrm{I}(1)$ & $\mathrm{I}(1)$ & $\mathrm{I}(1)$ \\
Lfbcf & $\mathrm{I}(1)$ & $\mathrm{I}(1)$ & $\mathrm{I}(0)$ & $\mathrm{I}(1)$ \\
Ldette & $\mathrm{I}(1)$ & $\mathrm{I}(1)$ & $\mathrm{I}(0)$ & $\mathrm{I}(1)$ \\
lrecette & $\mathrm{I}(1)$ & $\mathrm{I}(1)$ & $\mathrm{I}(1)$ & $\mathrm{I}(1)$ \\
Ldep & $\mathrm{I}(0)$ & $\mathrm{I}(1)$ & $\mathrm{I}(1)$ & $\mathrm{I}(1)$ \\
Lcredit & $\mathrm{I}(1)$ & $\mathrm{I}(1)$ & $\mathrm{I}(0)$ & $\mathrm{I}(1)$ \\
limport & $\mathrm{I}(1)$ & $\mathrm{I}(1)$ & $\mathrm{I}(0)$ & $\mathrm{I}(1)$ \\
Infpib & $\mathrm{I}(0)$ & $\mathrm{I}(0)$ & $\mathrm{I}(0)$ & $\mathrm{I}(0)$
\end{tabular}

Source: Calcul de l'auteur.

Table A2. Result of the optimal delay number.

\begin{tabular}{ccccccc}
\hline Lag & LogL & LR & FPE & AIC & SC & HQ \\
\hline 0 & 697.7498 & NA & $5.86 \mathrm{E}-10$ & -7.068875 & $-6.985250^{*}$ & -7.03502 \\
1 & 751.4759 & 104.163 & $4.37 \mathrm{E}-10$ & -7.361999 & -6.860247 & $-7.158866^{*}$ \\
2 & 777.3907 & 48.9208 & $4.33 \mathrm{E}-10^{*}$ & $-7.371334^{*}$ & -6.451455 & -6.998923 \\
3 & 796.9709 & 35.9635 & $4.58 \mathrm{E}-10$ & -7.316029 & -5.978023 & -6.77434 \\
4 & 821.8597 & 44.4444 & $4.60 \mathrm{E}-10$ & -7.314895 & -5.558762 & -6.603928 \\
5 & 832.3096 & 18.1273 & $5.35 \mathrm{E}-10$ & -7.166424 & -4.992165 & -6.28618 \\
6 & 840.698 & 14.1234 & $6.38 \mathrm{E}-10$ & -6.996919 & -4.404532 & -5.947397 \\
7 & 864.8232 & 39.388 & $6.49 \mathrm{E}-10$ & -6.987992 & -3.977479 & -5.769192 \\
8 & 889.5495 & $39.1078^{*}$ & $6.57 \mathrm{E}-10$ & -6.985199 & -3.556559 & -5.597121 \\
\hline
\end{tabular}

*indicates lag order selected by the criterion; LR: sequential modified modified LR test statistic (each test at 5\% level); FPE: Final prediction error; AIC: Akaike information criterion; SC: Schwarz information criterion; HQ: Hannan-Quinn information. 
Table A3. Result of the PVEC estimate.

\begin{tabular}{|c|c|c|c|c|c|}
\hline & CointEq1 & CointEq2 & CointEq3 & & \\
\hline lpibhbt $(-1)$ & 1 & - & - & & \\
\hline $\operatorname{ldep}(-1)$ & - & 1 & - & & \\
\hline lrecette $(-1)$ & - & - & 1 & & \\
\hline $\operatorname{ldette}(-1)$ & $74.85^{\star * *}$ & $2.044^{\star * *}$ & $20.624^{\star * *}$ & & \\
\hline limport(-1) & $86.053^{*}$ & $2.112^{*}$ & $22.959^{*}$ & & \\
\hline Trend & -0.099 & -0.003 & -0.028 & & \\
\hline $\mathrm{C}$ & -574.586 & -17.71 & -156.371 & & \\
\hline Error Corrector & $\mathrm{d}($ lpibhbt) & d(ldep) & Dlrecette & dldette & dlimport \\
\hline cointEq1 & 0.002 & -0.013 & $0.025^{\star *}$ & $0.181^{\star \star \star}$ & $-0.025^{\star}$ \\
\hline cointEq2 & 0.001 & $-0.251^{\star * *}$ & -0.046 & $0.521^{\star * *}$ & $0.096^{* * *}$ \\
\hline cointEq3 & -0.006 & 0.071 & $-0.088^{\star \star}$ & $-0.722^{\star * *}$ & $0.101^{\star *}$ \\
\hline dlpibhbt $(-1)$ & -0.004 & $0.379^{*}$ & $0.406^{* * *}$ & -1.386 & $0.409^{* * *}$ \\
\hline dlpibhbt $(-2)$ & 0.075 & -0.041 & 0.043 & -0.484 & 0.011 \\
\hline $\operatorname{dldep}(-1)$ & 0.008 & -0.025 & 0.065 & -0.257 & 0.076 \\
\hline dldep $(-2)$ & $0.005^{* *}$ & -0.007 & -0.008 & $-0.560^{* *}$ & 0.088 \\
\hline dlrecette $(-1)$ & 0.019 & -0.119 & $-0.215^{* * *}$ & 0.524 & -0.141 \\
\hline dlrecette $(-2)$ & 0.047 & 0.113 & -0.033 & 0.175 & -0.096 \\
\hline dldette $(-1)$ & -0.002 & 0.01 & 0.017 & $-0.332^{\star * *}$ & 0.005 \\
\hline dldette $(-2)$ & 0.001 & 0.021 & $0.030^{* * *}$ & $-0.108^{*}$ & 0.018 \\
\hline $\operatorname{dlimport}(-1)$ & $0.055^{\star *}$ & -0.02 & 0.1 & 0.103 & -0.096 \\
\hline dlimport(-2) & $-0.039^{\star}$ & -0.015 & $0.143^{* * *}$ & 0.345 & 0.037 \\
\hline C & $0.005^{* *}$ & -0.004 & 0.003 & -0.046 & -0.009 \\
\hline Dlfbcf & $0.076^{\star * *}$ & 0.085 & $0.130^{* * *}$ & $-0.593^{* * *}$ & $0.361^{\star * *}$ \\
\hline Dlcredit & -0.004 & 0.065 & 0.054 & $-0.369^{*}$ & -0.017 \\
\hline Infpib & -0.001 & 0.001 & 0.0004 & 0.009 & 0.002 \\
\hline
\end{tabular}

Source: Calcul de l’auteur. Significativité: ${ }^{* *} 1 \%,{ }^{*} 5 \%,{ }^{*} 1 \%$. 
Table A4. Results of the Granger causality test.

\begin{tabular}{|c|c|c|c|}
\hline Equation/Excluded & Chi2 & Df & Pro $>$ chi 2 \\
\hline \multicolumn{4}{|l|}{ Tcrel } \\
\hline detpubpib & 1.169 & 2 & 0.557 \\
\hline depubpib & 15.486 & 2 & 0.000 \\
\hline recpubpib & 2.403 & 2 & 0.301 \\
\hline importpib & 6.677 & 2 & 0.035 \\
\hline All & 29.004 & 8 & 0.000 \\
\hline Equation/Excluded & Chi2 & Df & Pro $>$ chi 2 \\
\hline \multicolumn{4}{|l|}{ Detpupib } \\
\hline tcrel & 12.237 & 2 & 0.02 \\
\hline depubpib & 16.632 & 2 & 0.000 \\
\hline recpubpib & 1.521 & 2 & 0.468 \\
\hline importpib & 7.936 & 2 & 0.019 \\
\hline All & 52.467 & 8 & 0.000 \\
\hline Equation/Excluded & Chi2 & Df & Pro $>$ chi 2 \\
\hline \multicolumn{4}{|l|}{ Depupib } \\
\hline tcrel & 12.324 & 2 & 0.02 \\
\hline detpubpib & 6.044 & 2 & 0.049 \\
\hline recpubpib & 9.674 & 2 & 0.008 \\
\hline importpib & 3.185 & 2 & 0.203 \\
\hline All & 34.123 & 8 & 0.000 \\
\hline Equation/Excluded & Chi2 & Df & Pro $>$ chi 2 \\
\hline \multicolumn{4}{|l|}{ Recpubpib } \\
\hline tcrel & 10.418 & 2 & 0.005 \\
\hline detpubpib & 3.514 & 2 & 0.173 \\
\hline depupib & 22.156 & 2 & 0.000 \\
\hline importpib & 2.391 & 2 & 0.303 \\
\hline All & 32.694 & 8 & 0.000 \\
\hline Equation/Excluded & Chi2 & Df & Pro $>$ chi 2 \\
\hline \multicolumn{4}{|l|}{ Importpib } \\
\hline tcrel & 3.646 & 2 & 0.162 \\
\hline detpubpib & 18.748 & 2 & 0.000 \\
\hline depupib & 13.598 & 2 & 0.001 \\
\hline recpubpib & 3.985 & 2 & 0.136 \\
\hline All & 45.893 & 8 & 0.000 \\
\hline
\end{tabular}

Source: Author's Calculation. 
Table A5. Result of autocorrelation test of final model residues.

\begin{tabular}{cccccc}
\hline \multicolumn{5}{c}{ Null hypothesis: no autocorrelation of delayed residues in h } \\
\hline \multicolumn{5}{c}{ Period : 1980 2016 } \\
\hline Retards h & Q-stats & Prob & Adj Q-stats & Prob & Df \\
\hline 1 & 5.022219 & $\mathrm{NA}^{*}$ & 5.043409 & $\mathrm{NA}^{*}$ & $\mathrm{NA}^{*}$ \\
2 & 11.05906 & $\mathrm{NA}^{*}$ & 11.13141 & $\mathrm{NA}^{*}$ & $\mathrm{NA}^{*}$ \\
3 & 30.45867 & 0.8029 & 30.77867 & 0.7909 & 38 \\
4 & 61.86495 & 0.5168 & 62.72181 & 0.4862 & 63 \\
5 & 84.70389 & 0.5797 & 86.05086 & 0.5389 & 88 \\
6 & 104.8197 & 0.6961 & 106.6869 & 0.6493 & 113 \\
7 & 140.7243 & 0.4196 & 143.6795 & 0.3530 & 138 \\
8 & 163.2227 & 0.4804 & 166.9605 & 0.3996 & 163
\end{tabular}

${ }^{\star}$ The test is valid only for delays greater than or equal to the order of the original VAR. df: degree of freedom. Source: Author's calculation. Significance: ${ }^{* *} 1 \%,{ }^{*} 5 \%,{ }^{\star} 1 \%$.
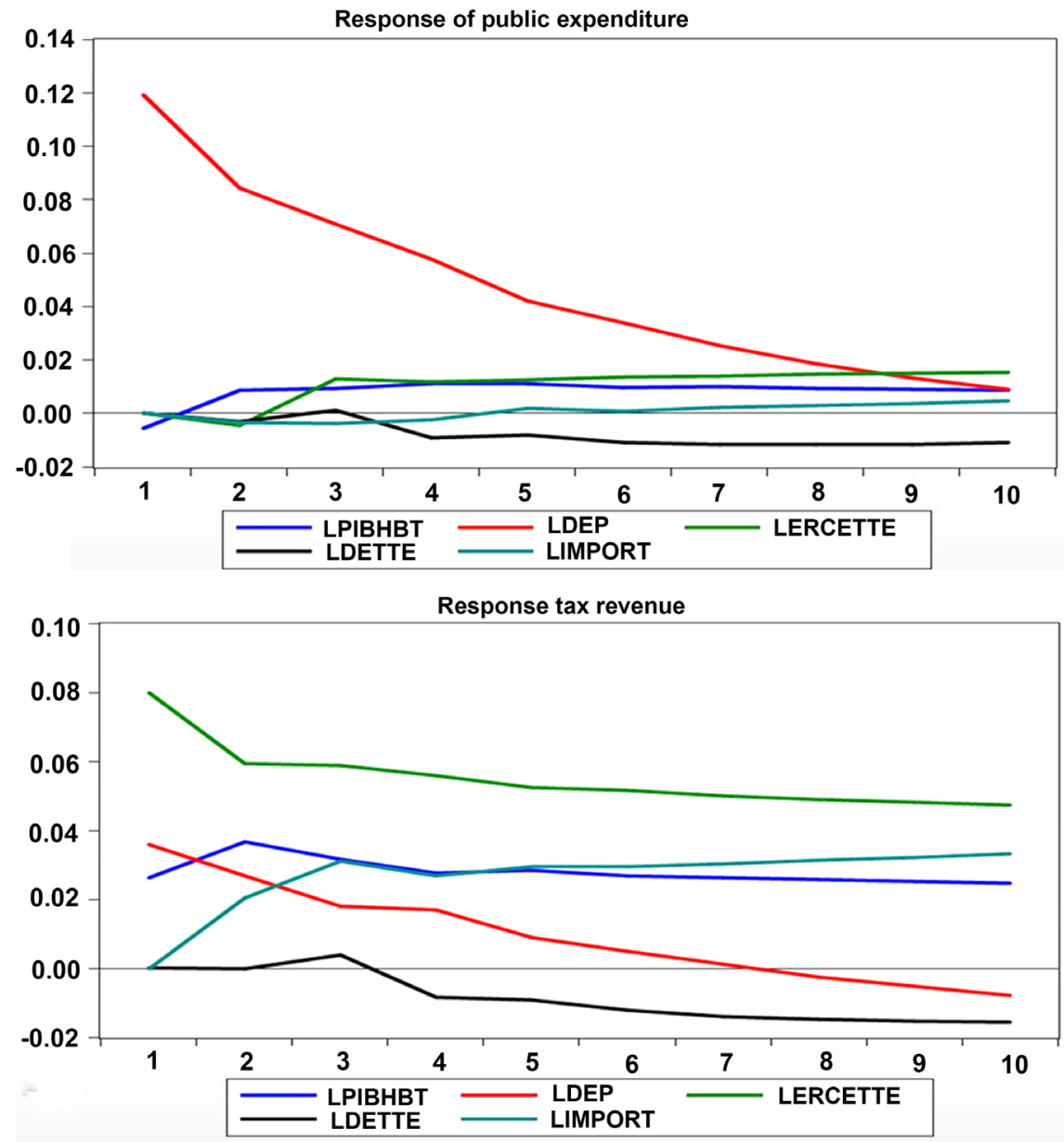

Figure A1. Impulse response functions (public expenditure and tax revenue). Source: Author's Calculationr. 